\title{
Von Hippel-Lindau disease
}

\section{PRASHANT CHITTIBOINA ${ }^{1,{ }^{*}}$ and RUSSELL R. LONSER ${ }^{1,2}$}

${ }^{1}$ Surgical Neurology Branch, National Institute of Neurological Disorders and Stroke, National Institutes of Health, Bethesda, MD, USA

${ }^{2}$ Department of Neurological Surgery, Ohio State University Wexner Medical Center, Columbus, $\mathrm{OH}$, USA

\section{INTRODUCTION}

Von Hippel-Lindau disease (VHL) is an inherited condition caused by genetic mutations of the VHL gene on chromosome 3 (Kaelin, 2002). Although the de novo manifestation of VHL has been documented in up to $20 \%$ of newly diagnosed cases, VHL typically presents as an inherited disease due to a germline mutation (Sgambati et al., 2000; Evans et al., 2010). VHL is transmitted through generations in an autosomal dominant fashion with near complete penetrance (Maher et al., 1991). VHL is characterized by formation of multiple benign and malignant tumors, as well as cysts in multiple organs (Fig. 10.1). Affected individuals frequently develop retinal and central nervous system hemangioblastomas, clear cell renal cell carcinomas (RCC), pheochromocytomas, pancreatic neuroendocrine tumors, and endolymphatic sac tumors (ELSTs) (Maher et al., 1990b; Lonser et al., 2003a).

\section{HISTORYAND CLINICAL DESCRIPTION}

\section{History}

Treacher Collins (1894) first described familial retinal hemangioblastomas in pathologic specimens from three enucleations from two siblings (Melmon and Rosen, 1964).

Separately, Eugene von Hippel studied the clinical appearance and progression of retinal lesions (now known as hemangioblastomas) (Hippel et al., 1904). Later, with pathologic confirmation from an enucleated specimen, he cited Collins and Czemark, and named the lesions angiomatosis retinae. Brandt reported the autopsy performed on the same patient 4 years later (Brandt, 1921). Visceral features included renal cysts and tumors as well as epididymal cysts (Melmon and Rosen, 1964; Lamiell et al., 1989).

It was Arvid Lindau who first proposed the term central nervous system angiomatosis, based on a review of clinical and pathologic features of 16 of his patients and 24 patients from literature (Lindau, 1927). His patients had developed cysts in the cerebellum that were

\footnotetext{
*Correspondence to: Prashant Chittiboina, MD, MPH, Staff Clinician, Surgical Neurology Branch, National Institute of Neurological Disorders and Stroke, National Institutes of Health, Bethesda, MD 20892, USA. Tel: +1-301-496-5728, Fax: +1-301-402-0380, prashant.chittiboina@nih.gov.

Resources

Suggested Screening Guidelines - VHL Alliance, VHL homepage - Zhejiang University Center for Genetic and Genomic Medicine (ZJU-CGGM) - Leiden Open Variation Database.
} 
associated with mural nodules. He found that the cysts and tumors were found in medulla and spinal cord in association with retinal hemangioblastomas and visceral tumors. Since his publication, authors have shortened the descriptive term to the eponymous von HippelLindau disease in acknowledgement of the two authors' descriptions: retinal hemangioblastomas (von Hippel tumors) and cerebellar hemangioblastomas (Lindau's tumors) (Melmon and Rosen, 1964).

\section{Diagnostic criteria}

Melmon and Rosen (1964) were the first to propose clinical criteria for the clinical diagnosis of VHL. They recognized cerebellar hemangioblastomas as the hallmark Lindau's tumor. Lindau's disease (now know as VHL) was defined as the association of a cerebellar hemangioblastoma with one of the following: retinal hemangioblastoma, pancreatic cyst, renal or epididymal abnormalities. They recognized the inherited nature of the disease, as well as the variable penetrance and delayed expression. They proposed expanding the diagnostic criteria to include patients with only one of the lesions of the complex in the presence of central nervous system hemangioblastomas in a family member. The definition for clinical diagnosis of VHL was later refined by Lamiell and others (Lamiell et al., 1989; Lonser et al., 2003a) to include an expanded list of associated visceral tumors.

Contemporary diagnostic criteria for VHL often include both genetic and clinical findings (Friedrich, 1999; Binderup et al., 2013; Lonser et al., 2014).

Currently, the following manifestations are included in clinical diagnostic critera (Lonser et al., 2003a; Butman et al., 2007; Maher et al., 2011; Binderup et al., 2013):

1. central nervous system hemangioblastoma (including retinal hemangioblastoma)

2. endolymphatic sac tumors (ELST) (Manski et al., 1997)

3. renal cell carcinoma (RCC)

4. pheochromocytoma, paraganglioma, and/or glomus tumor

5. neuroendocrine neoplasm and/or multiple cysts of the pancreas (Hammel et al., 2000).

The diagnosis of VHL is made if an individual has the following combination of manifestations of genetic/family factors:

1. at least two central nervous system hemangioblastomas

2. at least one central nervous system hemangioblastoma and one other manifestation described above

3. at least one of the manifestations described above, and a pathogenic mutation in $V H L$ gene or a first-degree relative with VHL.

Using advances in genetic testing, including DNA sequencing and semiquantitave Southern blotting, a VHL mutation can now be identified in nearly 100\% patients (Stolle et al., 1998). Diagnosis of VHL is particularly challenging in apparent de novo appearance without a family history. In these cases, mosaicism in peripheral blood leukocytes that do not carry the 
VHL mutation could result in a false negative genetic test. Careful clinical testing and mutation analysis in other tissues or VHL manifestations may reveal the presence of VHL in these instances (Sgambati et al., 2000; Nordstrom-O'Brien et al., 2010).

\section{EPIDEMIOLOGY}

The incidence of VHL ranges from 1 in 36000 to 1 in 45000 live births (Maher et al., 1991; Maddock et al., 1996; Evans et al., 2010). VHL has a point prevalence of 1 in 38000 to 1 in 91000 persons (Maher et al., 1991; Neumann and Wiestler, 1991; Maddock et al., 1996; Evans et al., 2010). Typically, VHL first manifests in the second decade of life (Table 10.1). At the time of detection, 50\% of patients are symptomatic (Poulsen et al., 2010). Cerebellar hemangioblastomas (35\%) are the most common presenting manifestation of VHL (Maddock et al., 1996). Penetrance of VHL is almost complete by 70 years of age (Table 10.2) (Maher et al., 1991; Poulsen et al., 2010). With improved imaging and other diagnostic tools, first manifestations of VHL are diagnosed sooner. Analysis of 82 Dutch VHL patients suggests that over $95 \%$ of patients will have a first manifestation by 34 years of age (Kruizinga et al., 2014). Recently, researchers have reported evidence of progressively earlier age of onset and more severe presentation in successive generations. The phenomenon is known as genetic anticipation and may be due to shortening of telomere length (Ning et al., 2014).

Life expectancy for VHL patients historically has been between 40 and 52 years (Maher et al., 1990b; Akcaglar et al., 2008; Wilding et al., 2012). Currently, unlike the general population, male life expectancy (59.4 years) is significantly higher then female (48.4 years) (Wilding et al., 2012). Despite understanding and treatment advances, life expectancy in VHL remains the lowest among common inherited tumor syndromes (Wilding et al., 2012). Early reports established that the major cause of mortality could be either central nervous system (CNS) hemangioblastomas (Lamiell et al., 1989; Maddock et al., 1996) or RCC (Maher et al., 1990b). However, in VHL patients that manifest with CNS hemangioblastoma, these tumors remain the primary cause of death (Lonser et al., 2014). Death in VHL patients is more likely (73\%) due to VHL-related causes than unrelated causes (Wilding et al., 2012).

\section{MOLECULARGENETICS}

\section{The VHL gene}

Linkage studies indicate that the $V H L$ gene is a tumor suppressor gene on chromosome 3p25-26. Genetic alterations leading to loss of function of this gene were observed in both VHL kindreds and in sporadic RCC patients (Seizinger et al., 1988). The VHL gene was isolated and sequenced in 1993 (Latif et al., 1993). It consists of three exons and encodes the VHL protein, a glycan-anchored membrane protein responsible for signal transduction (Latif et al., 1993). The gene is highly conserved across species (Woodward et al., 2000). VHL conforms to the Knudson " $t$ wo-hit' model of hereditary cancer (Knudson and Strong, 1972; Knudson, 1986; Kaelin, 2002). A germline VHL mutation results in a defective allele in all cells of the body (first hit). However, a second, somatic event is required for tumor formation (second hit or loss of heterozygosity) (Knudson, 1986). 
Hemangioblastomas and RCC in VHL patients follow a single-stage somatic mutation model (Maher et al., 1990a). Indeed, the second hit hypothesis is supported by studies showing somatic VHL gene mutations (two-stage) in about $20 \%$ of sporadic hemangioblastomas (Kanno et al., 1994; Tse et al., 1997; Lee et al., 1998) and up to 90\% of sporadic clear cell RCC (Gnarra et al., 1994; Gallou et al., 1999; Kondo et al., 2002b). Nevertheless, although some VHL mutations can lead to increased incidence of pheochromocytomas, $V H L$ gene mutations are rare (3\%) in sporadic pheochromocytomas (Gnarra et al., 1994; Brauch et al., 1997).

\section{The VHL protein}

The VHL gene encodes the VHL protein (pVHL), which is composed of 213 amino acid residues and has a molecular weight of 24-30 kDa. A second, smaller isoform with a molecular weight of $19 \mathrm{kDa}$ can be found in many tissues. This form of pVHL arises as a result of alternate translation initiation from codon 54 (Iliopoulos et al., 1998). VHL occurs when inactivating mutations occur between codon 54 and the carboxy terminal, affecting both isoforms of protein. pVHL is found in both nuclear and cytoplasmic compartments. Trafficking between these two compartments is essential for pVHL function (Lee et al., 1999).

The best characterized function of pVHL is the targeting of hypoxia inducible factor (HIF) for proteasomal degradation ( $\mathrm{Li}$ and $\mathrm{Kim}, 2011)$. HIF is a heterodimeric transcription factor consisting of an unstable alpha (a) and a stable beta $(\beta)$ subunit. There are three known human HIF-a genes. The isoforms are not completely redundant (Wang et al., 2005). In some conditions, HIF-1a and HIF-2a may be mutually antagonistic (Yuan et al., 2013). HIF-3a appears to be involved in a feedback mechanism controlling HIF-1a activity (Mandriota et al., 2002). pVHL binds elongin C, which in turns binds elongin B and CUL2 to form the VCB-CUL2 complex.

In normoxic conditions, VCB-CUL2 complex binds HIF-a and polyubiquitinates it, targeting it for proteasomal degradation (Fig. 10.2). HIF-a undergoes hydroxylation under normoxic conditions within the oxygen-dependent degradation domain (ODD). Hydroxylation allows binding of pVHL and VCB-CUL2 complex, leading to ubiquitination and proteasomal degradation. Under hypoxic conditions, HIF-a binds cyclic AMP response element binding protein and transcriptional coactivator p300 to activate transcription of HIFregulated genes. When pVHL is inactivated, tumor-igenesis may occur through HIFmediated effects or through direct effects of pVHL (Kaelin, 2002; Lonser et al., 2003a; Maher et al., 2011).

\section{Tumorigenesis in VHL}

The pVHL/HIF pathway has been implicated in tumorigenesis for RCC (Krieg et al., 2000), retinal hemangioblastomas (Wang et al., 2014), CNS (Vortmeyer et al., 2006) hemangioblastomas, and neuroendocrine tumors of the pancreas (PNETs) (Périgny et al.,). pVHL 2009 inactivation leads to increased expression and stabilization of HIF proteins in VHL-related tumors (Krieg et al., 2000; Wang et al., 2014). Specifically, HIF-2a is necessary and sufficient for RCC (Kondo et al., 2002a, 2003; Zimmer et al., 2004). HIF-2a 
also may be required for CNS (Shively et al., 2008) and retinal (Wang et al., 2014) hemangioblastoma formation and growth. HIF can lead to tumorigenesis by differential upregulation of over 50 genes, including genes for growth factors (TGF, PDGF), angiogenesis (VEGF), and glucose metabolism (GLUT1, PFK1). Moreover, HIF can lead to activation of genes that affect tumor microenvironment (LOX, MMP1) (Lee et al., 1998; Wang et al., 2005). Loss of pVHL activity may lead to tumorigenesis via HIF-independent pathways as well. pVHL has been implicated in regulation of apoptosis (p53 inactivation and increased NF- $\kappa$ B activity), stabilization of microtubules and regulation of extracellular matrix (Li and Kim, 2011).

\section{Mechanism of $V H L$ gene inactivation}

Most patients with VHL inherit a germline mutation from an affected parent and a wild type allele from the unaffected parent (Maddock et al., 1996). The most common germline mutations are missense mutations (27-38\%) and nonsense mutations (13-27\%). Large (9$20 \%$ ) or microdeletions $(10 \%)$, as well as rearrangements $(25 \%)$, account for a majority of the remaining germline mutations. Insertions or splice-site mutations are rare (Stolle et al., 1998; Friedrich, 1999). Somatic mutation events leading to homozygous inactivation of the VHL alleles are tumorigenic. These "second hit" events are frequently allelic loss (49\%) or hypermethylation (35\%) of the wild type allele (Prowse et al., 1997). Somatic inactivation of the wild type allele may also occur due to point mutations, especially in instances of large deletion of 3p as a "first hit" (Wait et al., 2004).

\section{Genotype-phenotype correlation}

Subclassification of VHL into types 1, 2A, 2B or 2C was based initially on clinical phenotypic manifestations. Early kindred studies reported familial clustering of manifestations in VHL carriers. High frequency of retinal hemangioblastomas (51\%), CNS hemangioblastomas (46\%), and renal cell cancers $(33 \%)$ were found in all kindreds. Alternatively, pheochromocytomas were seen in only $20 \%$ of kindreds. No members of other kindreds manifested pheochromocytomas, pointing to distinct subsets of patients with VHL. Specifically, type 1 kindreds are without pheochromocytomas and type 2 have pheochromocytomas (Table 10.3) (Lamiell et al., 1989; Neumann and Wiestler, 1991).

Type 1 disease is likely caused by mutations leading to severe disruption of protein activity, including deletions, nonsense mutations, and other microdeletions/insertions (Chen et al., 1995; Crossey et al., 1995). Missense mutations that lead to structural changes in pVHL also give rise to the type 1 VHL phenotype (Ong et al., 2007). Further, subclassifications have been suggested based on observations that large VHL gene (exon 1 only or exon 1,2,3) deletions that include the neighboring C3orf10 gene may lead to lower incidence of RCC. Concurrent VHL and C3orf10 inactivation in RCC is hypothesized to lead to a growth disadvantage for tumor cells. This in turn, may lead to a significantly lower lifetime risk of RCC (type 1B) (McNeill et al., 2009).

Type 2 disease nearly always (78-96\%) is associated with missense mutations (Chen et al., 1995; Zbar et al., 1996). The missense mutations leading to type 2 disease result in a substitution of an amino acid on the surface of the protein and may predict a high lifetime 
risk of pheochromocytoma (Ong et al., 2007). VHL type 2 families from the Black Forest region of Germany all shared a low risk of RCC (hence designated type 2A). These 16 families were discovered to share a distinct missense mutation (p.Tyr169His) of the $V H L$ gene with a founder effect confirmed on haplotype analysis (Brauch et al., 1995). Missense mutations of codon 167 (e.g., p. Arg167Gln or p.Arg167Trp) can lead to a VHL type 2B phenotype with a high risk of RCC (60\% at 60 years) and pheochromocytomas (82\% at 50 years) (Maher et al., 1996; Zbar et al., 1996). Rare kindreds with only pheochromocytomas were found to have specific missense mutations at VHL codons 238, 259 and other rare point mutations. Originally diagnosed with multiple endocrine neoplasia (MEN) type 2, the kindreds were reclassified as VHL type 2C (Crossey et al., 1995; Neumann et al., 1995; Woodward et al., 1997).

\section{Genetic testing}

Genetic testing is performed when VHL is suspected because of clinical presentation in a patient or a relative (Binderup et al., 2013). After obtaining a medical history and a family history, a clinical examination should be performed prior to mutation testing. Peripheral blood samples are obtained for mutation testing. To identify cases of mosaicism, peripheral blood from the affected parent is preferred. An analysis for duplication and deletions is performed by using Southern blotting to detect whole gene deletions, Southern blotting to detect gene rearrangements, and fluorescence in situ hybridization (FISH) to confirm deletions (Stolle et al., 1998). Alternatively, multiplex ligation-dependent probe amplification (MLPA) may be used to detect deletions and insertions (Binderup et al., 2013). Sequencing of the $V H L$ gene is performed including the coding exons and intron-exon boundaries. Sequence variations are compared with the 377 known intragenic mutations associated with VHL disease (see Resources; Schmidt and Linehan, 2014). When mutation screening fails to identify a mutation in the peripheral blood, screening of DNA from other tissues and/or from VHL manifestations may be necessary to confirm diagnosis (Binderup et al., 2013).

\section{CENTRAL NERVOUS SYSTEM LESIONS}

\section{Central nervous system hemangioblastomas}

General features-CNS hemangioblastomas are among the most common manifestations in VHL disease. Up to $72 \%$ of VHL patients may present with a CNS hemangioblastoma in the cerebellum (16-69\%), brainstem (5-22\%), spinal cord (13-53\%), cauda equina (11\%), or supratentorial (1-7\%) locations (Filling-Katz et al., 1991; Poulsen et al., 2010; Binderup et al., 2013; Huntoon and Lonser, 2014; Lonser et al., 2014). Patients present with these lesions in their second or third decade. CNS hemangioblastomas are the most common (3035\%) and often the first manifestation of VHL (Maddock et al., 1996; Poulsen et al., 2010). Although benign, hemangioblastomas are a significant source of morbidity and mortality in VHL patients due to mass effect on CNS structures (Wanebo et al., 2003; Lonser et al., 2014).

Clinical, imaging, and histologic findings-Mass effect occurs due to tumor growth, edema formation and/or cyst formation. When observed for longer than 5 years, over $50 \%$ of 
hemangioblastomas will grow. Tumor growth progresses commonly (72\%) in a saltatory fashion with periods of quiescence, but tumors also can show linear (6\%) or exponential (22\%) growth patterns. A patient may harbor various tumors that demonstrate different rates and patterns of growth (Wanebo et al., 2003; Wind and Lonser, 2011; Lonser et al., 2014). Symptoms arise from mass effect on neighboring neural structures (Table 10.4) (Lonser et al., 2014). High tumor burden is associated with male sex and partial germline deletion. New tumors form more frequently in younger patients and those with a higher tumor burden at initial visit (Lonser et al., 2014).

Imaging: Contrast-enhanced magnetic resonance (MR) imaging is the gold standard for detecting and monitoring CNS hemangioblastomas (Filling-Katz et al., 1989; Choyke et al., 1995). Hemangioblastomas as small as $2 \mathrm{~mm}$ can be visualized as discrete enhancing lesions on contrast-enhanced T1-weighted images (Fig. 10.3). Fluid-attenuated inversion recovery (FLAIR) and T2-weighted images are used to detect hemangioblastoma-associated edema or cyst formation (Butman et al., 2008). Arteriography can be used to assess vascular supply and drainage for large tumors (Huson et al., 1986; Neumann et al., 1989; Peyre et al., 2010; Wind et al., 2011; Lonser et al., 2014).

Gross appearance and histology: During surgical resection, hemangioblastomas appear as distinct, red, vascular masses with a thin layer of capsule. Histologically, the tumors consist of polygonal stromal cells, and numerous vascular structures (see Fig. 10.3), both of which carry the somatic second hit (Zhuang et al., 2014). Larger tumor-associated blood vessels derive from reactive migrating endothelial cells from the surrounding, normal tissues. Multipotent hemangioblasts are the cells of origin for the stromal cells, and de novo tumor blood vessels (by vasculogenesis) (Shively et al., 2008, 2011; Zhuang et al., 2014).

Treatment-Microsurgical resection is the treatment of choice for CNS hemangioblastomas. Safe and complete resection of hemangioblastomas can be performed in most cases (Lonser et al., 2003b, 2014; Weil et al., 2003; Peyre et al., 2010; Wind et al., 2011). Circumferential dissection using meticulous microsurgical technique allows resection of these tumors with minimal blood loss. Preoperative embolization to reduce intraoperative bleeding is not routinely used and can be associated with additional risk (Lonser et al., 2003a).

Stereotactic radiation or craniospinal radiation has been used in patients who are not surgical candidates. However, long term follow-up reveals that radiation-treated hemangioblastomas will continue to grow in a proportion similar to that expected by natural history studies (Chang et al., 1998; Asthagiri et al., 2010; Simone et al., 2011). Given the unpredictable nature of growth patterns in VHL-related hemangioblastomas, prophylactic radiation is not advised except for tumors that are not surgically accessible or that cannot be removed safely (Lonser et al., 2003a, 2014).

Effect of pregnancy-Multiple case reports have described an initial diagnosis of VHL or worsening of clinical manifestations of VHL with pregnancy (Ogasawara et al., 1995; Othmane et al., 1999; Capone et al., 2013). Nevertheless, a prospective natural history study of VHL failed to find any significant differences in either appearance of new 
hemangioblastomas ( $p=0.6$ ), the rates of hemangioblastoma growth ( $p=0.6$ ), development of new tumors/cysts ( 0.4 tumors/year; $0.1 \pm-0.1$ cysts/year) or the rate of growth of associated cysts $(p=0.4)$. Since hemangioblastomas in VHL have an unpredictable growth pattern (Wanebo et al., 2003), management in pregnant patients can be guided by onset of symptoms rather than a change in the size of lesions on imaging (Ye et al., 2012).

\section{Retinal hemangioblastomas}

General features-Retinal hemangioblastomas occur very frequently in VHL patients. Between $49 \%$ and $62 \%$ of VHL patients will develop retinal hemangioblastomas (Poulsen et al., 2010; Toy et al., 2012; Wittström et al., 2014). Retinal hemangioblastomas are often the first manifestation of VHL, with the lowest median age of onset (21 years) among the various manifestations of VHL (Kreusel et al., 2006; Poulsen et al., 2010). Most hemangioblastomas (61\%) are symptomatic at presentation and all patients with at least one retinal hemangioblastoma will develop bilateral disease by 56 years of age (Kreusel et al., 2006; Toy et al., 2012). The presence of retinal hemangioblastomas is highly suggestive of VHL (Singh et al., 2002; Binderup et al., 2013). Retinal hemangioblastomas can lead to blindness or severe visual deficits in 5-8\% of VHL patients (Kreusel et al., 2006; Toy et al., 2012; Wittström et al., 2014).

Clinical findings-Retinal hemangioblastomas may occur at the periphery $(50 \%)$ or at the optic nerve (50\%) (Wittström et al., 2014). An increase in the number of lesions and complications from the retinal hemangioblastomas can lead to blindness in $15 \%$ of affected eyes (Wittström et al., 2014). Both peripheral and optic nerve tumors can lead to symptoms due to accumulation of subretinal fluid and formation of hard exudates at the macula (Fig. 10.4) (Lonser et al., 2003a). Lesions located in close proximity to the macula negatively impact visual function (Wong et al., 2008). Younger age at onset of ocular disease, involvement of the fellow eye and missense or protein truncating mutations can lead to worse visual outcomes (Wong et al., 2008a; Toy et al., 2012).

Fundoscopic evaluation-Dilated fundoscopy and slit lamp examinations are performed to analyze ocular manifestations of VHL. Fluorescein angiography is used to confirm the presence of newly diagnosed lesions. The patients are closely followed with wide-angle photography to document the lesions and changes due to disease progression (Kreusel et al., 2006; Wong et al., 2008a; Toy et al., 2012).

Histologic findings-Retinal hemangioblastomas are grossly and histologically similar to CNS hemangioblastomas. Retinal gliosis and hemorrhages are present in association with severe lesions. Differential upregulation of HIF-2a has been demonstrated in severe lesions that are refractory to anti-VEGF therapy (Lonser et al., 2003a; Wang et al., 2014).

Treatment-Laser photocoagulation and cryotherapy are the mainstays of surgical management of retinal hemangioblastomas. Either of these methods can be used to as a sole method for treatment of extrapapillary hemangioblastomas (Singh et al., 2002). Vitreoretinal surgery can be performed when preretinal and vitreal membranes, retinal detachment from traction, and exudation occur (Machemer and Williams, 1988; Johnson et al., 1992). For 
hemangioblastomas in close proximity to the optic nerve, intravitreal anti-VEGF therapy may arrest progression for small lesions and may help reverse exudates and edema in some cases (Wong et al., 2008b; Hrisomalos et al., 2010). Photodynamic therapy or plaque radiotherapy may have a limited role in the management of retinal hemangioblastomas (Kreusel et al., 1998; Lazzeri et al., 2011; Stattin et al., 2014). Salvage external beam radiation may be used for treatment-refractory retinal hemangioblastomas with reduction in tumor volume and improvement in visual acuity (Raja et al., 2004).

\section{Endolymphatic sac tumors}

General features-Endolymphatic sac tumors (ELSTs) arise from the endolymphatic epithelium within the vestibular aqueduct (Lonser et al., 2008). These tumors are rare in the general population but are found in up to 6-15\% of VHL patients (Manski et al., 1997; Lonser et al., 2003a; Choo et al., 2004; Butman et al., 2007). Bilateral ELSTs are found only in VHL (Lonser et al., 2003a).

Clinical-ELSTs arise within the vestibular aqueduct, and can lead to hearing loss due to intralabrynthine hemorrhage, endolymphatic hydrops, and/or by otic capsule invasion (Butman et al., 2007). ELSTs can present with vestibular symptoms (62\%), partial or complete hearing loss (95 to 100\%), tinnitus (77\%), and/or facial paresis (8\%) (Manski et al., 1997).

Imaging-High resolution computed tomography (CT) scans of the temporal bone and pre-/postcontrast enhanced MR imaging of the internal auditory canals are necessary to detect and follow these tumors (Fig. 10.5). CT is used to detect the presence of otic capsule invasion and to evaluate the extent of bony erosion of the temporal bone (particularly, the vestibular aqueduct in very small tumors). Postcontrast T1-weighted MR imaging can reveal signs of small ELST tumors as subtle asymmetric enhancement of the endolymphatic sac. Larger tumors are heterogeneously enhancing on postcontrast T1W images. Intralabrynthine hemorrhage is detected by increased signal on precontrast T1W images (Lonser et al., 2003a; Kim et al., 2005; Butman et al., 2007).

Histologic findings-ELSTs are papillary cystic glandular neoplasms with variegated patterns (see Fig. 10.5). Due to the presence of local bone invasion, these tumors were called low grade adenocarcinoma of probable endolymphatic origin (Heffner, 1989). ELSTs may be found entirely within the endolymphatic sac when small. When large, these inevitably invade and erode the surrounding temporal bone (Lonser et al., 2008).

Treatment-Surgery is the treatment of choice for ELSTs. Complete resection may be achieved in a majority of cases with minimal risk for recurrence (3\%) after gross total resection (Kim et al., 2013). Surgical resection of the tumor can relieve audiovestibular symptoms and can preserve hearing in a majority of cases (Kim et al., 2005, 2013). Indications for treatment of ELSTs include progressive sensorineural hearing loss, vestibular symptoms, facial nerve compression, and local mass effect from tumor growth. Early resection of ELSTs is recommended to prevent sensorineural hearing loss and to alleviate vestibular symptoms. Facial nerve decompression (large tumors) performed during surgery 
can improve facial nerve function in some cases (Kim et al., 2013). The role of radiation in the management of ELST is unproven (Lonser et al., 2003a; Poletti et al., 2013).

\section{VISCERAL LESIONS}

\section{Renal cell carcinomas and renal cysts}

General features-RCC may affect up to $30 \%$ of VHL patients. Multiple renal cysts are often found along with RCC in up to $60 \%$ of VHL patients (Fig. 10.6). The patients typically develop RCC and renal cysts bilaterally starting in their third and fourth decades of life (Lonser et al., 2003a; Bausch et al., 2013; Binderup et al., 2013). The frequency of RCC increases with age and up to 70\% of VHL patients develop RCC by 60 years of age (Maher et al., 1990b). VHL patients frequently develop lesions that range from simple cysts to entirely solid lesions. Solid components of cystic lesions invariably contain RCC (Choyke et al., 1995). Although simple cysts may form precursor lesions for later development of RCC, such transformation is rare (Neumann and Wiestler, 1991; Choyke et al., 1995). Each kidney may contain up to 1100 cysts and 600 RCC foci (Manski et al., 1997; Wind and Lonser, 2011). Solid masses and complex cysts may grow over time, but, simple cysts tend to remain indolent, or may even involute (Choyke et al., 1992).

Clinical-RCC or renal cysts are rarely (less than 7\%) the first manifestation of VHL (Poulsen et al., 2010). When present, large RCCs may present with classic findings of a renal mass with flank pain, hematuria and/or a flank mass. Simple renal cysts tend to be asymptomatic, while complex cysts may progress to solid RCC masses (Choyke et al., 1992; Lonser et al., 2003a; Bausch et al., 2013). VHL patients may maintain renal function despite multiple renal cysts (Bausch et al., 2013).

Imaging - Surveillance imaging with abdominal CT is the most sensitive method to detect renal involvement (see Fig. 10.6). Multidetector CT scanning allows for discrimination of complex from simple cysts and identification of surgical lesions. Abdominal MR imaging is often accurate in differentiating between complex and simple cysts (Beer et al., 2006).

Histologic features-Both cysts and RCC in VHL are the clear cell type (see Fig. 10.6) (Walther et al., 1995). Although, histologically similar to sporadic clear cell carcinomas, VHL-related RCC is morphologically distinct in bilaterality, multifocality, and association with renal cysts. VHL-associated RRCs often have lower grade histology and are only known to metastasize when greater than $3 \mathrm{~cm}$ in diameter (Neumann et al., 1998).

Treatment-RCC lesions below $3 \mathrm{~cm}$ in diameter on CT images do not metastasize. Consequently, a $3 \mathrm{~cm}$ threshold is often recommended for surgical resection (Walther et al., 1999). Nephron sparing surgery performed to resect lesions larger than $3 \mathrm{~cm}$ allows longterm preservation of renal function and 10 year cancer specific survival rates of up to $81 \%$ (Steinbach et al., 1995; Duffey et al., 2004). First-line surgery for RCC has moved away from total nephrectomies to nephron sparing surgeries (partial nephrectomies). Recently, radiofrequency ablation has been used (Joly et al., 2011). 


\section{Pheochromocytomas}

General features-Pheochromocytomas arise most commonly in the adrenal medulla and are found in up to 16\% of VHL patients (Lonser et al., 2003a; Binderup et al., 2013). Pheochromocytomas in VHL can be bilateral and occasionally multifocal (see Fig. 10.6) (Lenders et al., 2005). Pheochromocytomas in extra-adrenal locations (paragangliomas), including carotid body, glomus jugulare, and periaortic tissues, are rare in VHL and are more likely to be due to germ-line succinate dehydrogenase (SDH) mutation or sporadic tumors (Neumann et al., 2002). Pheochromocytomas in VHL present in the second decade of life (mean age 18-20 years), and rarely (1-5\%) transform to malignant tumors (Walther et al., 1999; Neumann et al., 2002; Lenders et al., 2005; Bausch et al., 2014).

Clinical-Pheochromocytomas in VHL produce norepinephrine in excess and may result in paroxysmal or sustained hypertension, palpitations, tachycardia, headaches, sweating, pallor, and nausea (Lonser et al., 2003a; Lenders et al., 2005). Occasionally, these tumors may present as hypertensive crises in children younger than 10 years of age.

Laboratory and imaging findings-Diagnosis of pheochromocytomas is made by biochemical testing demonstrating excess catecholamines and imaging. Traditional tests include urinary and plasma catecholamines, urinary metanephrines (normetaneprhine and metanephrine), and urinary vanillymandelic acid (VMA). Recently, plasma levels of free fractions of metanephrines have been used to reliably detect pheochromocytomas with high sensitivity (97\%) and specificity (93\%) (Pamporaki et al., 2013).

Imaging is used to localize the tumor once there is biochemical evidence for pheochrmocytomas. While postcontrast CT scans of the abdomen are sensitive in detecting adrenal and abdominal extra-adrenal pheochromocytomas, adrenergic blockade is needed before injecting iohexol contrast to prevent a hypertensive crisis or cardiac arrhythmia from catecholamine release.

Contrasted MR imaging of the abdomen has similar sensitivity (90-100\%) to CT for detecting abdominal pheochromocytomas. MR imaging is often the preferred imaging modality (versus CT), since adrenergic blockade is not needed prior to gadolinium contrast injection. Nevertheless, CT and MRI imaging have a specificity that ranges from $70 \%$ to 80\% (Lenders et al., 2005; Sahdev et al., 2005). To improve specificity and to detect extraadrenal/multifocal pheochromocytomas, ${ }^{131}$ I-metaiodobenzylguanidine (MIBG) scanning may be used (specificity 100\%) (Shapiro et al., 1985).

Perioperative management-In VHL patients, pheochromocytomas can lead to catecholamine-induced, potentially life-threatening complications, including hypertensive crises, cardiac arrhythmias, pulmonary edema, and myocardial ischemia/infarction. Elective surgeries in VHL patients with pheochromocytomas may need preoperative a adrenergic blockade. Blockade can be achieved with phenoxybenzamine (nonselective a adrenergic blocker), prazosin, doxazosin or urapidil for 10-14 days. In patients who have tachyarrhythmias, a $\beta$-blocker may be added after a few days of a blockade. Postoperatively, patients with adrenergic blockade are monitored for hypotension and hypoglycemia (Kinney et al., 2000; Chen et al., 2010; King and Pacak, 2014). 
Treatment-Laparoscopic surgery is the treatment of choice of pheochromocytomas and paragangliogliomas (Hwang et al., 2004; Chen et al., 2010; Moraitis et al., 2014). In VHL patients, partial adrenalectomies are performed via laparoscopic approach. Patients need long-term follow-up to evaluate for recurrence of pheochromocytomas in the remnant adrenal cortex (Lonser et al., 2003a; Chen et al., 2010).

\section{Pancreatic neuroendocrine tumors and cysts}

General features-VHL patients can develop a variety of pancreatic lesions. Up to $72 \%$ of VHL patients will have pancreatic cysts on autopsy. In nearly half (47\%) of these patients, the cysts may be the only form of pancreatic pathology (Hough et al., 1994; Charlesworth et al., 2012). Cysts are commonly multiple (84\%) and asymptomatic (94\%). In $12 \%$ of patients, pancreatic cysts may be seen as the only manifestation of VHL, before other manifestations develop (Charlesworth et al., 2012). Serous cystadenomas are multiloculated lesions of the pancreas that are usually benign and asymptomatic (Mohr et al., 2000). Neuroendocrine tumors of the pancreas (PNET) are found in 15-56\% of VHL patients (Hough et al., 1994; Blansfield et al., 2007; Charlesworth et al., 2012). PNETs can become malignant and metastasize in $8 \%$ of VHL patients (Blansfield et al., 2007). Occasionally, pancreatic adenocarcinomas or metastatic tumors from RCC can be found in the pancreas (Charlesworth et al., 2012).

Clinical-Cysts and cystadenomas can cause exocrine or endocrine deficiency by replacing the pancreatic parenchyma. Compression of intestine or the bile duct can lead to symptomatic pancreatic cysts (Blansfield et al, 2007). PNETs are mostly nonfunctional and are rarely the cause of major morbidity or mortality in VHL patients. Nevertheless, malignant conversion or metastasis of PNETs leads to poor prognoses (average survival of 1-3 years) (Weisbrod et al., 2014). VHL patients with metastatic PNETs are likely to have exon 3 mutations compared to those that do not have metastasis ( $80 \%$ versus $46 \%$ ). Other indicators of tumor aggression include tumor size greater than $3 \mathrm{~cm}$ and a tumor doubling time of less than 500 days (Libutti et al., 2000; Blansfield et al., 2007; Charlesworth et al., 2012).

Imaging-Pre- and postcontrast abdominal CT and MR imaging can be used to diagnose pancreatic lesions. Abdominal CT images are favored for surveillance of simple and complex pancreatic lesions at intervals determined by presence of symptoms, previous evidence of growth or solid lesions (see Fig. 10.6) (Weisbrod et al., 2014). Recently, FDG positron emission tomography (PET) has been used to detect PNETs not visible by CT. Furthermore, FDG PET can detect metastatic lesions (Sadowski et al., 2014).

Histologic features-True cysts and cystadenomas contain prominent fibrous stroma, clear, glycogen-rich epithelial cells with numerous epithelial cells forming small vessels in the tumors (Mohr et al., 2000). PNETs historically were called islet cell tumors. PNETs arise from the pancreatic islets and the tumor cells stain for pancreatic and gastrointestinal hormones (Hough et al., 1994; Lonser et al., 2003a). 
Treatment-Treatment is usually not required for asymptomatic cysts. Laparoscopic surgical decompression is performed for cysts that are causing obstructive symptoms. Enucleation or selective pancreatic resections are performed for PNETs that have a higher likelihood for metastasis (greater than $3 \mathrm{~cm}$, exon 3 mutation, and doubling time more than 500 days) (Blansfield et al., 2007; Libutti et al., 2000; Charlesworth et al., 2012; Weisbrod et al., 2014).

\section{Epididymal cystadenomas}

General features-Cystadenomas develop in the epididymis unilaterally or bilaterally in 25-60\% of males who have VHL (Gruber et al., 1980; Lonser et al., 2003a). These tumors are benign and rarely need surgical resection. The tumors are derived from the mesonephric ducts and share the morphologic features of other VHL manifestations (Mehta et al., 2008).

Clinical, imaging, and histologic findings-Epididymal cystadenomas are typically asymptomatic. Patients may become aware of firm masses above the testes. In about $17 \%$ of the patients, the lesions are too small to be palpated, but can be detected by ultrasonography (Choyke et al., 1997). These masses may also be a target for metastasis of RCC tumors (Mehta et al., 2007).

Epididymal cystadenomas are grossly solid but contain multiple cysts filled with colloid material. Microscopically, the cysts are lined by clear epithelial cells, and are surrounded by dense stroma.

Treatment-Epididymal cystadenomas are typically monitored by physical examination and ultrasonography. Surgery is needed rarely for symptomatic tumors. Surgical indications for removal of epididymal cystadenomas can include local discomfort (Gruber et al., 1980; Choyke et al., 1997; Lonser et al., 2003a).

\section{Broad ligament cystadenomas}

General features-Papillary cystadenomas of the broad ligament are rare, and appear to arise from the mesonephric remnants. Papillary cystadenomas are found in the mesosalpinx and the broad ligament (Gersell and King, 1988; Werness and Guccion, 1997). The tumors may be found unilaterally or bilaterally in women with VHL disease (Zanotelli et al., 2010; Nogales et al., 2012). The incidence and prevalence of this tumor in VHL remains unknown (Lonser et al., 2003a).

Clinical, imaging, and histologic findings-Papillary cystadenomas are usually asymptomatic. Occasionally, the tumor may present as an abdominopelvic mass with symptoms of abdominal discomfort or present as a painful adnexal mass (Lonser et al., 2003a; Nogales et al., 2012). The masses may be detected by abdominal MR imaging or pelvic ulstrasonography (Zanotelli et al., 2010).

Papillary cystadenomas have a prominent papillary architecture with fibrovascular and hyalinized stromal cores similar to cystadenomas or the epididymis (Zanotelli et al., 2010; Brady et al., 2012; Nogales et al., 2012). 
Treatment-Papillary cystadenomas are resected typically when found incidentally during caesarean section surgery or rarely due to symptoms of pelvic mass (Zanotelli et al., 2010; Nogales et al., 2012). In most cases, papillary cystadenomas remain asymptomatic and are followed with serial imaging (Lonser et al., 2003a).

\section{SCREENING AND SURVEILLANCE}

\section{Screening for VHL}

Initial screening workup includes a thorough history and clinical examination, an ophthalmologic examination including fundoscopy, MR imaging of the craniospinal axis, kidneys, pancreas, and liver, an audiologic examination and laboratory tests (to detect pheochromocytomas) (Binderup et al., 2013). Genetic testing of the peripheral leukocytes and/or other body tissues is performed to confirm the presence of a $V H L$ gene mutation (Nordstrom-O'Brien et al., 2010). Genetic testing may be useful in patients who present with known manifestations of VHL (Binderup et al., 2013). The incidence of VHL in patients presenting with hemangioblastomas is as high as 30-40\% (Huson et al., 1986; Neumann et al., 1989; Sora et al., 2001). A higher percentage of patients with retinal hemangioblastomas (up to 81\%) may be VHL carriers (Wanebo et al., 2003; Kreusel et al., 2006). The frequency of VHL among patients with pheochromocytomas (2-11\%), ELST (5$15 \%$ ) or PNET (1\%) is lower but may warrant screening for VHL (Binderup et al., 2013). Genetic testing can allow for discontinuation of surveillance for family members that do not carry VHL mutations. Early diagnosis of VHL mutation carriers allows initiation of appropriate screening procedures, and to improve morbidity and mortality (Gläsker et al., 1999; Rasmussen et al., 2010).

\section{Surveillance}

Recommendations for surveillance of patients and carriers with VHL have been generated by the US National Institutes of Health (Choyke et al., 1995; Lonser et al., 2003a), the Danish VHL Coordination Group (Poulsen et al., 2010, 2011; Binderup et al., 2013), and the VHL Family Alliance (see Resources and Table 10.4).

\section{PREVENTION AND GENETIC COUNSELING}

Prenatal diagnosis and preimplantation genetic diagnosis for at-risk pregnancies (either parent with known VHL disease or mutation) should be provided (Simpson et al., 2005). To prevent misinterpretation of test results, referral to a genetic counselor is recommended. Secondary effects from VHL manifestations are mitigated by routine surveillance and early detection. Risk of renal cancer may be increased by exposure to tobacco products and other toxins. Contact sports should be avoided if adrenal or pancreatic lesions are present (Frantzen et al., 2012).

\section{References}

Akcaglar S, Yavascaoglu I, Vuruskan H, et al. Genetic evaluation of von Hippel-Lindau disease for early diagnosis and improved prognosis. Int Urol Nephrol. 2008; 40:615-620. [PubMed: 18074239] 
Asthagiri AR, Mehta GU, Zach L, et al. Prospective evaluation of radiosurgery for hemangioblastomas in von Hippel-Lindau disease. Neuro Oncol. 2010; 12:80-86. [PubMed: 20150370]

Bausch B, Jilg C, Gläsker S, et al. Renal cancer in von Hippel-Lindau disease and related syndromes. Nat Rev Nephrol. 2013; 9:529-538. [PubMed: 23897319]

Bausch B, Wellner U, Bausch D, et al. Long-term prognosis of patients with pediatric pheochromocytoma. Endocr Relat Cancer. 2014; 21:17-25. [PubMed: 24169644]

Beer AJ, Dobritz M, Zantl N, et al. Comparison of 16-MDCT and MRI for characterization of kidney lesions. Am J Roentgenol. 2006; 186:1639-1650. [PubMed: 16714654]

Binderup MLM, Bisgaard ML, Harbud V, et al. Von Hippel-Lindau disease (vHL). National clinical guideline for diagnosis and surveillance in Denmark. 3rd edition. Dan Med J. 2013; 60:B4763. [PubMed: 24355456]

Blansfield JA, Choyke L, Morita SY, et al. Clinical, genetic and radiographic analysis of 108 patients with von Hippel-Lindau disease (VHL) manifested by pancreatic neuroendocrine neoplasms (PNETs). Surgery. 2007; 142:814-818. discussion 818.e811-812. [PubMed: 18063061]

Brady A, Nayar A, Cross P, et al. A detailed immunohistochemical analysis of 2 cases of papillary cystadenoma of the broad ligament: an extremely rare neoplasm characteristic of patients with von Hippel-Lindau disease. Int J Gynecol Pathol. 2012; 31:133-140. [PubMed: 22317868]

Brandt R. Zur Frage der Angiomatosis retinae. Graefes Archiv Clin Exp Ophthalmol. 1921; 106:127165.

Brauch H, Kishida T, Glavac D, et al. Von Hippel-Lindau (VHL) disease with pheochromocytoma in the Black Forest region of Germany: evidence for a founder effect. Hum Genet. 1995; 95:551-556. [PubMed: 7759077]

Brauch H, Hoeppner W, Jähnig H, et al. Sporadic pheochromocytomas are rarely associated with germline mutations in the VHL tumor suppressor gene or the ret protooncogene. J Clin Endocrinol Metab. 1997; 82:4101-4104. [PubMed: 9398721]

Butman JA, Kim HJ, Baggenstos M, et al. Mechanisms of morbid hearing loss associated with tumors of the endolymphatic sac in von Hippel-Lindau disease. JAMA. 2007; 298:41-48. [PubMed: 17609489]

Butman JA, Linehan WM, Lonser RR. Neurologic manifestations of von Hippel-Lindau disease. JAMA. 2008; 300:1334-1342. [PubMed: 18799446]

Capone F, Profice P, Pilato F, et al. Spinal hemangioblastoma presenting with low back pain in pregnancy. Spine J. 2013; 13:e27-e29.

Chang SD, Meisel JA, Hancock SL, et al. Treatment of hemangioblastomas in von Hippel-Lindau disease with linear accelerator-based radiosurgery. Neurosurgery. 1998; 43:28-34. discussion 3425. [PubMed: 9657185]

Charlesworth M, Verbeke CS, Falk GA, et al. Pancreatic lesions in von Hippel-Lindau disease? A systematic review and meta-synthesis of the literature. J Gastrointest Surg. 2012; 16:1422-1428. [PubMed: 22370733]

Chen F, Kishida T, Yao M, et al. Germline mutations in the von Hippel-Lindau disease tumor suppressor gene: correlations with phenotype. Hum Mutat. 1995; 5:66-75. [PubMed: 7728151]

Chen H, Sippel RS, O’Dorisio MS, et al. The North American Neuroendocrine Tumor Society consensus guideline for the diagnosis and management of neuroendocrine tumors: pheochromocytoma, paraganglioma, and medullary thyroid cancer. Pancreas. 2010; 39:775-783. [PubMed: 20664475]

Choo D, Shotland L, Mastroianni M, et al. Endolymphatic sac tumors in von Hippel-Lindau disease. J Neurosurg. 2004; 100:480-487. [PubMed: 15035284]

Choyke PL, Glenn GM, Walther MM, et al. The natural history of renal lesions in von Hippel-Lindau disease: a serial CT study in 28 patients. Am J Roentgenol. 1992; 159:1229-1234. [PubMed: 1442389]

Choyke PL, Glenn GM, Walther MM, et al. von Hippel-Lindau disease: genetic, clinical, and imaging features. Radiology. 1995; 194:629-642. [PubMed: 7862955]

Choyke PL, Glenn GM, Wagner JP, et al. Epididymal cystadenomas in von Hippel-Lindau disease. Urology. 1997; 49:926-931. [PubMed: 9187702] 
Collins TE. Two cases, brother and sister, with peculiar vascular new growth, probably primarily retinal, affecting both eyes. Trans Ophthalmol Soc U K. 1894; 14(141-149):1894.

Crossey PA, Eng C, Ginalska-Malinowska M, et al. Molecular genetic diagnosis of von Hippel-Lindau disease in familial phaeochromocytoma. J Med Genet. 1995; 32:885-886. [PubMed: 8592333]

Duffey BG, Choyke PL, Glenn G, et al. The relationship between renal tumor size and metastases in patients with von Hippel-Lindau disease. J Urol. 2004; 172:63-65. [PubMed: 15201738]

Evans DG, Howard E, Giblin C, et al. Birth incidence and prevalence of tumor-prone syndromes: estimates from a UK family genetic register service. Am J Med Genet A. 2010; 152A:327-332. [PubMed: 20082463]

Filling-Katz MR, Choyke PL, Patronas NJ, et al. Radiologic screening for von Hippel-Lindau disease: the role of Gd-DTPA enhanced MR imaging of the CNS. J Comput Assist Tomogr. 1989; 13:743755. [PubMed: 2778131]

Filling-Katz MR, Choyke PL, Oldfield E, et al. Central nervous system involvement in Von HippelLindau disease. Neurology. 1991; 41:41-46. [PubMed: 1985294]

Frantzen, C.; Links, TP.; Giles, RH. Von Hippel-Lindau Disease. University of Washington; Seattle: 2012.

Friedrich CA. Von Hippel-Lindau syndrome. A pleomorphic condition. Cancer. 1999; 86:2478-2482. [PubMed: 10630173]

Gallou C, Joly D, Méjean A, et al. Mutations of the VHL gene in sporadic renal cell carcinoma: definition of a risk factor for VHL patients to develop an RCC. Hum Mutat. 1999; 13:464-475. [PubMed: 10408776]

Gersell DJ, King TC. Papillary cystadenoma of the mesosalpinx in von Hippel-Lindau disease. Am J Surg Pathol. 1988; 12:145-149. [PubMed: 3341511]

Gläsker S, Bender BU, Apel TW, et al. The impact of molecular genetic analysis of the VHL gene in patients with haemangioblastomas of the central nervous system. J Neurol Neurosurg Psychiatry. 1999; 67:758-762. [PubMed: 10567493]

Gnarra JR, Tory K, Weng Y, et al. Mutations of the VHL tumour suppressor gene in renal carcinoma. Nat Genet. 1994; 7:85-90. [PubMed: 7915601]

Gruber MB, Healey GB, Toguri AG, et al. Papillary cystadenoma of epididymis: component of von Hippel-Lindau syndrome. Urology. 1980; 16:305-306. [PubMed: 7423716]

Hammel PR, Vilgrain V, Terris B, et al. Pancreatic involvement in von Hippel-Lindau disease. Gastroenterology. 2000; 119:1087-1095. [PubMed: 11040195]

Heffner DK. Low-grade adenocarcinoma of probable endolymphatic sac origin. A clinicopathologic study of 20 cases. Cancer. 1989; 64:2292-2302. [PubMed: 2804921]

Hippel E, Netzhaut ED, Beobachtungen K. Über eine sehr seltene Erkrankung der Netzhaut. Graefes Archiv Clin Exp Ophthalmol. 1904; 59:83-106.

Hough DM, Stephens DH, Johnson CD. Pancreatic lesions in von Hippel-Lindau disease: prevalence, clinical significance, and CT findings. Am J Roentgenol. 1994; 162:1091-1094. [PubMed: 8165988]

Hrisomalos FN, Maturi RK, Pata V. Long-term use of intravitreal bevacizumab (Avastin) for the treatment of von Hippel-Lindau associated retinal hemangioblastomas. Open Ophthalmol J. 2010; 4:66-69. [PubMed: 21293730]

Huntoon K, Lonser RR. Findings from the natural history of central nervous system hemangioblastomas in von Hippel-Lindau disease. Neurosurgery. 2014; 61(Suppl 1):N159-N162. [PubMed: 25032659]

Huson SM, Harper PS, Hourihan MD, et al. Cerebellar haemangioblastoma and von Hippel-Lindau disease. Brain. 1986; 109:1297-1310. [PubMed: 3790978]

Hwang J, Shoaf G, Uchio EM, et al. Laparoscopic management of extra-adrenal pheochromocytoma. J Urol. 2004; 171:72-76. [PubMed: 14665847]

Igarashi H, Ito T, Nishimori I, et al. Pancreatic involvement in Japanese patients with von HippelLindau disease: results of a nationwide survey. J Gastroenterol. 2014; 49:511-516. [PubMed: 23543325] 
Iliopoulos O, Ohh M, Kaelin WG. pVHL19 is a biologically active product of the von Hippel-Lindau gene arising from internal translation initiation. Proc Natl Acad Sci U S A. 1998; 95:1166111666. [PubMed: 9751722]

Johnson MW, Flynn HW, Gass JD. Pars plana vitrectomy and direct diathermy for complications of multiple retinal angiomas. Ophthalmic Surg. 1992; 23:47-50. [PubMed: 1574268]

Joly D, Méjean A, Corréas J-M, et al. Progress in nephron sparing therapy for renal cell carcinoma and von Hippel-Lindau disease. J Urol. 2011; 185:2056-2060. [PubMed: 21496837]

Kaelin WG. Molecular basis of the VHL hereditary cancer syndrome. Nat Rev Cancer. 2002; 2:673682. [PubMed: 12209156]

Kanno H, Kondo K, Ito S, et al. Somatic mutations of the von Hippel-Lindau tumor suppressor gene in sporadic central nervous system hemangioblastomas. Cancer Res. 1994; 54:4845-4847. [PubMed: 8069849]

Kim HJ, Butman JA, Brewer C, et al. Tumors of the endolymphatic sac in patients with von HippelLindau disease: implications for their natural history, diagnosis, and treatment. J Neurosurg. 2005; 102:503-512. [PubMed: 15796386]

Kim HJ, Hagan M, Butman JA, et al. Surgical resection of endolymphatic sac tumors in von HippelLindau disease: findings, results, and indications. Laryngoscope. 2013; 123:477-483. [PubMed: 23070752]

King KS, Pacak K. Familial pheochromocytomas and paragangliomas. Mol Cell Endocrinol. 2014; 386:92-100. [PubMed: 23933153]

Kinney MA, Warner ME, vanHeerden JA, et al. Perianesthetic risks and outcomes of pheochromocytoma and paraganglioma resection. Anesth Analg. 2000; 91:1118-1123. [PubMed: 11049893]

Knudson AG. Genetics of human cancer. Ann Rev Genet. 1986; 20:231-251. [PubMed: 2880556]

Knudson AG Jr, Strong LC. Mutation and cancer: neuroblastoma and pheochromocytoma. Am J Hum Genet. 1972; 24:514-532. [PubMed: 4340974]

Kondo K, Klco J, Nakamura E, et al. Inhibition of HIF is necessary for tumor suppression by the von Hippel-Lindau protein. Cancer Cell. 2002a; 1:237-246. [PubMed: 12086860]

Kondo K, Yao M, Yoshida M, et al. Comprehensive mutational analysis of the VHL gene in sporadic renal cell carcinoma: relationship to clinicopathological parameters. Genes Chromosomes Cancer. 2002b; 34:58-68. [PubMed: 11921283]

Kondo K, Kim WY, Lechpammer M, et al. Inhibition of HIF2alpha is sufficient to suppress pVHLdefective tumor growth. PLoS Biol. 2003; 1:E83. [PubMed: 14691554]

Kreusel KM, Bornfeld N, Lommatzsch A, et al. Ruthenium-106 brachytherapy for peripheral retinal capillary hemangioma. Ophthalmology. 1998; 105:1386-1392. [PubMed: 9709747]

Kreusel K-M, Bechrakis NE, Krause L, et al. Retinal angiomatosis in von Hippel-Lindau disease: a longitudinal ophthalmologic study. Ophthalmology. 2006; 113:1418-1424. [PubMed: 16769118]

Krieg M, Haas R, Brauch H, et al. Up-regulation of hypoxia-inducible factors HIF-1 a and HIF-2 a under normoxic conditions in renal carcinoma cells by von Hippel-Lindau tumor suppressor gene loss of function. Oncogene. 2000; 19:5435-5443. [PubMed: 11114720]

Kruizinga RC, Sluiter WJ, de Vries EGE, et al. Calculating optimal surveillance for detection of von Hippel-Lindau-related manifestations. Endocr Relat Cancer. 2014; 21:63-71. [PubMed: 24132471]

Lamiell JM, Salazar FG, Hsia YE. von Hippel-Lindau disease affecting 43 members of a single kindred. Medicine. 1989; 68:1-29. [PubMed: 2642584]

Latif F, Tory K, Gnarra J, et al. Identification of the von Hippel-Lindau disease tumor suppressor gene. Science. 1993; 260:1317-1320. [PubMed: 8493574]

Lazzeri S, Figus M, Di Bartolo E, et al. Verteporfin photodynamic therapy for retinal hemangioblastoma associated with von Hippel-Lindau disease in a 9-year-old child. Clin Experiment Ophthalmol. 2011; 39:179-181. [PubMed: 21040313]

Lee JY, Dong SM, Park WS. Loss of heterozygosity and somatic mutations of the VHL tumor suppressor gene in sporadic cerebellar hemangioblastomas. Cancer Res. 1998; 58:504-508. [PubMed: 9458097] 
Lee S, Neumann M, Stearman R, et al. Transcription-dependent nuclear-cytoplasmic trafficking is required for the function of the von Hippel-Lindau tumor suppressor protein. Mol Cell Biol. 1999; 19:1486-1497. [PubMed: 9891082]

Lenders JWM, Eisenhofer G, Mannelli M, et al. Phaeochromocytoma. Lancet. 2005; 366:665-675. [PubMed: 16112304]

Li M, Kim WY. Two sides to every story: the HIF-dependent and HIF-independent functions of pVHL. J Cell Mol Med. 2011; 15:187-195. [PubMed: 21155973]

Libutti SK, Choyke PL, Alexander HR, et al. Clinical and genetic analysis of patients with pancreatic neuroendocrine tumors associated with von Hippel-Lindau disease. Surgery. 2000; 128:10221027. discussion 1027-1028. [PubMed: 11114638]

Lindau A. Zur Frage der Angiomatosis Retinae und Ihrer Hirnkomplikationen. Acta Ophthalmol. 1927; 4:193-226.

Lonser RR, Glenn GM, Walther M, et al. von Hippel-Lindau disease. Lancet. 2003a; 361:2059-2067. [PubMed: 12814730]

Lonser RR, Weil RJ, Wanebo JE, et al. Surgical management of spinal cord hemangioblastomas in patients with von Hippel-Lindau disease. J Neurosurg. 2003b; 98:106-116. [PubMed: 12546358]

Lonser RR, Baggenstos M, Kim HJ, et al. The vestibular aqueduct: site of origin of endolymphatic sac tumors. J Neurosurg. 2008; 108:751-756. [PubMed: 18377255]

Lonser RR, Butman JA, Huntoon K, et al. Prospective natural history study of central nervous system hemangioblastomas in von Hippel-Lindau disease. J Neurosurg. 2014; 120:1055-1062. [PubMed: 24579662]

Machemer R, Williams JM. Pathogenesis and therapy of traction detachment in various retinal vascular diseases. Am J Ophthalmol. 1988; 105:170-181. [PubMed: 3341435]

Maddock IR, Moran A, Maher ER, et al. A genetic register for von Hippel-Lindau disease. J Med Genet. 1996; 33:120-127. [PubMed: 8929948]

Maher ER, Yates JR, Ferguson-Smith MA. Statistical analysis of the two stage mutation model in von Hippel-Lindau disease, and in sporadic cerebellar haemangioblastoma and renal cell carcinoma. J Med Genet. 1990a; 27:311-314. [PubMed: 2352258]

Maher ER, Yates JR, Harries R, et al. Clinical features and natural history of von Hippel-Lindau disease. Q J Med. 1990b; 77:1151-1163. [PubMed: 2274658]

Maher ER, Iselius L, Yates JR, et al. Von Hippel-Lindau disease: a genetic study. J Med Genet. 1991; 28:443-447. [PubMed: 1895313]

Maher ER, Webster AR, Richards FM, et al. Phenotypic expression in von Hippel-Lindau disease: correlations with germline VHL gene mutations. J Med Genet. 1996; 33:328-332. [PubMed: 8730290]

Maher ER, Neumann HP, Richard S. von Hippel-Lindau disease: a clinical and scientific review. Eur J Hum Genet. 2011; 19:617-623. [PubMed: 21386872]

Mandriota SJ, Turner KJ, Davies DR, et al. HIF activation identifies early lesions in VHL kidneys: evidence for site-specific tumor suppressor function in the nephron. Cancer Cell. 2002; 1:459-468. [PubMed: 12124175]

Manski TJ, Heffner DK, Glenn GM, et al. Endolymphatic sac tumors. A source of morbid hearing loss in von Hippel-Lindau disease. JAMA. 1997; 277:1461-1466. [PubMed: 9145719]

McNeill A, Rattenberry E, Barber R, et al. Genotype-phenotype correlations in VHL exon deletions. Am J Med Genet A. 2009; 149A:2147-2151. [PubMed: 19764026]

Mehta GU, Shively SB, Gläsker S, et al. von Hippel-Lindau disease: epididymal cystadenoma targeted by metastatic events. Urology. 2007; 69:1209.e1209-e1212.

Mehta GU, Shively SB, Duong H, et al. Progression of epididymal maldevelopment into hamartomalike neoplasia in VHL disease. Neoplasia. 2008; 10:1146-1153. [PubMed: 18813354]

Melmon KL, Rosen SW. Lindau's disease. Review of the literature and study of a large kindred. Am J Med. 1964; 36:595-617. [PubMed: 14142412]

Mohr VH, Vortmeyer AO, Zhuang Z, et al. Histopathology and molecular genetics of multiple cysts and microcystic (serous) adenomas of the pancreas in von Hippel-Lindau patients. Am J Pathol. 2000; 157:1615-1621. [PubMed: 11073821] 
Moraitis AG, Martucci VL, Pacak K. Genetics, diagnosis, and management of medullary thyroid carcinoma and pheochromocytoma/paraganglioma. Endocr Pract. 2014; 20:176-187. [PubMed: 24449662]

Neumann HP, Wiestler OD. Clustering of features of von Hippel-Lindau syndrome: evidence for a complex genetic locus. Lancet. 1991; 337:1052-1054. [PubMed: 1673491]

Neumann HP, Eggert HR, Weigel K, et al. Hemangioblastomas of the central nervous system. A 10year study with special reference to von Hippel-Lindau syndrome. J Neurosurg. 1989; 70:24-30. [PubMed: 2909683]

Neumann HP, Eng C, Mulligan LM, et al. Consequences of direct genetic testing for germline mutations in the clinical management of families with multiple endocrine neoplasia, type II. JAMA. 1995; 274:1149-1151. [PubMed: 7563486]

Neumann HP, Bender BU, Berger DP, et al. Prevalence, morphology and biology of renal cell carcinoma in von Hippel-Lindau disease compared to sporadic renal cell carcinoma. J Urol. 1998; 160:1248-1254. [PubMed: 9751329]

Neumann HPH, Bausch B, McWhinney SR, et al. Germline mutations in nonsyndromic pheochromocytoma. N Engl J Med. 2002; 346:1459-1466. [PubMed: 12000816]

Ning XH, Zhang N, Li T, et al. Telomere shortening is associated with genetic anticipation in Chinese Von Hippel-Lindau disease families. Cancer Res. 2014; 74:3802-3809. [PubMed: 24986515]

Nogales FF, Goyenaga P, Preda O, et al. An analysis of five clear cell papillary cystadenomas of mesosalpinx and broad ligament: four associated with von Hippel-Lindau disease and one aggressive sporadic type. Histopathology. 2012; 60:748-757. [PubMed: 22296276]

Nordstrom-O'Brien M, van der Luijt RB, van Rooijen E, et al. Genetic analysis of von Hippel-Lindau disease. Hum Mutat. 2010; 31:521-537. [PubMed: 20151405]

Ogasawara KK, Ogasawara EM, Hirata G. Pregnancy complicated by von Hippel-Lindau disease. Obstet Gynecol. 1995; 85:829-831. [PubMed: 7724127]

Ong KR, Woodward ER, Killick P, et al. Genotype-phenotype correlations in von Hippel-Lindau disease. Hum Mutat. 2007; 28:143-149. [PubMed: 17024664]

Othmane IS, Shields C, Singh A, et al. Postpartum cerebellar herniation in von Hippel-Lindau syndrome. Am J Ophthalmol. 1999; 128:387-389. [PubMed: 10511048]

Pamporaki C, Därr R, Bursztyn M, et al. Plasma-free vs deconjugated metanephrines for diagnosis of phaeochromocytoma. Clin Endocrinol (Oxf). 2013; 79:476-483. [PubMed: 23461656]

Périgny M, Hammel P, Corcos O, et al. Pancreatic endocrine microadenomatosis in patients with von Hippel-Lindau disease: characterization by VHL/HIF pathway proteins expression. Am J Surg Pathol. 2009; 33:739-748. [PubMed: 19238077]

Peyre M, David P, Van Effenterre R, et al. Natural history of supratentorial hemangioblastomas in von Hippel-Lindau disease. Neurosurgery. 2010; 67:577-587. discussion 587. [PubMed: 20647972]

Poletti AM, Dubey SP, Barbò R, et al. Sporadic endolymphatic sac tumor: its clinical, radiological, and histological features, management, and follow-up. Head Neck. 2013; 35:1043-1047. [PubMed: 22367728]

Poulsen ML, Budtz-Jørgensen E, Bisgaard ML. Surveillance in von Hippel-Lindau disease (vHL). Clin Genet. 2010; 77:49-59. [PubMed: 19863552]

Poulsen ML, Gimsing S, Kosteljanetz M, et al. von Hippel-Lindau disease: surveillance strategy for endolymphatic sac tumors. Genet Med. 2011; 13:1032-1041. [PubMed: 21912262]

Prowse AH, Webster AR, Richards FM, et al. Somatic inactivation of the VHL gene in Von HippelLindau disease tumors. Am J Hum Genet. 1997; 60:765-771. [PubMed: 9106522]

Raja D, Benz MS, Murray TG, et al. Salvage external beam radiotherapy of retinal capillary hemangiomas secondary to von Hippel-Lindau disease: visual and anatomic outcomes. Ophthalmology. 2004; 111:150-153. [PubMed: 14711727]

Rasmussen A, Alonso E, Ochoa A, et al. Uptake of genetic testing and long-term tumor surveillance in von Hippel-Lindau disease. BMC Med Genet. 2010; 11:4. [PubMed: 20064270]

Sadowski SM, Weisbrod AB, Ellis R, et al. Prospective evaluation of the clinical utility of 18fluorodeoxyglucose PET CT scanning in patients with von Hippel-Lindau-associated pancreatic lesions. J Am Coll Surg. 2014; 218:997-1003. [PubMed: 24661849] 
Sahdev A, Sohaib A, Monson JP, et al. CT and MR imaging of unusual locations of extra-adrenal paragangliomas (pheochromocytomas). Eur Radiol. 2005; 15:85-92. [PubMed: 15290072]

Schmidt LS, Linehan WM. Editorial comment. Urology. 2014; 83:675.e675. discussion 675.e675-676.

Seizinger BR, Rouleau GA, Ozelius LJ, et al. Von Hippel-Lindau disease maps to the region of chromosome 3 associated with renal cell carcinoma. Nature. 1988; 332:268-269. [PubMed: 2894613]

Sgambati MT, Stolle C, Choyke PL, et al. Mosaicism in von Hippel-Lindau disease: lessons from kindreds with germline mutations identified in offspring with mosaic parents. Am J Hum Genet. 2000; 66:84-91. [PubMed: 10631138]

Shapiro B, Copp JE, Sisson JC, et al. Iodine-131 metaiodobenzylguanidine for the locating of suspected pheochromocytoma: experience in 400 cases. J Nucl Med. 1985; 26(576-585):1985.

Shively SB, Beltaifa S, Gehrs B, et al. Protracted haemangioblastic proliferation and differentiation in von Hippel-Lindau disease. J Pathol. 2008; 216:514-520. [PubMed: 18836991]

Shively SB, Falke EA, Li J, et al. Developmentally arrested structures preceding cerebellar tumors in von Hippel-Lindau disease. Mod Pathol. 2011; 24:1023-1030. [PubMed: 21499240]

Simone CB, Lonser RR, Ondos J, et al. Infratentorial craniospinal irradiation for von Hippel-Lindau: a retrospective study supporting a new treatment for patients with CNS hemangioblastomas. Neuro Oncol. 2011; 13:1030-1036. [PubMed: 21798886]

Simpson JL, Carson SA, Cisneros P. Preimplantation genetic diagnosis (PGD) for heritable neoplasia. J Natl Cancer Inst Monogr. 2005; 34:87-90.

Singh AD, Nouri M, Shields CL, et al. Treatment of retinal capillary hemangioma. Ophthalmology. 2002; 109:1799-1806. [PubMed: 12359597]

Sora S, Ueki K, Saito N, et al. Incidence of von Hippel-Lindau disease in hemangioblastoma patients: the University of Tokyo Hospital experience from 1954-1998. Acta Neurochir (Wien). 2001; 143:893-896. [PubMed: 11685621]

Stattin M, Kralinger M, Haas G, et al. Photodynamic therapy for retinal capillary hemangioblastoma. Can J Ophthalmol. 2014; 49:e32-e35. [PubMed: 24513380]

Steinbach F, Novick AC, Zincke H, et al. Treatment of renal cell carcinoma in von Hippel-Lindau disease. J Urol. 1995; 4:1812-1816.

Stolle C, Glenn G, Zbar B, et al. Improved detection of germline mutations in the von Hippel-Lindau disease tumor suppressor gene. Hum Mutat. 1998; 12:417-423. [PubMed: 9829911]

Toy BC, Agrón E, Nigam D, et al. Longitudinal analysis of retinal hemangioblastomatosis and visual function in ocular von Hippel-Lindau disease. Ophthalmology. 2012; 119:2622-2630. [PubMed: 22906772]

Tse JY, Wong JH, Lo KW, et al. Molecular genetic analysis of the von Hippel-Lindau disease tumor suppressor gene in familial and sporadic cerebellar hemangioblastomas. Am J Clin Pathol. 1997; 107:459-466. [PubMed: 9124215]

Vortmeyer AO, Tran MGB, Zeng W, et al. Evolution of VHL tumourigenesis in nerve root tissue. J Pathol. 2006; 210:374-382. [PubMed: 16981244]

Wait SD, Vortmeyer AO, Lonser RR, et al. Somatic mutations in VHL germline deletion kindred correlate with mild phenotype. Ann Neurol. 2004; 55:236-240. [PubMed: 14755727]

Walther MM, Lubensky IA, Venzon D, et al. Prevalence of microscopic lesions in grossly normal renal parenchyma from patients with von Hippel-Lindau disease, sporadic renal cell carcinoma and no renal disease: clinical implications. J Urol. 1995; 154:2010-2014. discussion 2014-2015. [PubMed: 7500446]

Walther MM, Reiter R, Keiser HR, et al. Clinical and genetic characterization of pheochromocytoma in von Hippel-Lindau families: comparison with sporadic pheochromocytoma gives insight into natural history of pheochromocytoma. J Urol. 1999; 162:659-664. [PubMed: 10458336]

Wanebo JE, Lonser RR, Glenn GM, et al. The natural history of hemangioblastomas of the central nervous system in patients with von Hippel-Lindau disease. J Neurosurg. 2003; 98:82-94. [PubMed: 12546356]

Wang V, Davis DA, Haque M, et al. Differential gene up-regulation by hypoxia-inducible factor-1alpha and hypoxia-inducible factor-2alpha in HEK293T cells. Cancer Res. 2005; 65:3299-3306. [PubMed: 15833863] 
Wang Y, Abu-Asab MS, Shen D, et al. Upregulation of hypoxia-inducible factors and autophagy in von Hippel-Lindau-associated retinal hemangioblastoma. Graefes Archiv Clin Exp Ophthalmol. 2014; 252:1319-1327.

Webster AR, Richards FM, MacRonald FE, et al. An analysis of phenotypic variation in the familial cancer syndrome von Hippel-Lindau disease: evidence for modifier effects. Am J Hum Genet. 1998; 63:1025-1035. [PubMed: 9758595]

Weil RJ, Lonser RR, DeVroom HL, et al. Surgical management of brainstem hemangioblastomas in patients with von Hippel-Lindau disease. J Neurosurg. 2003; 98:95-105. [PubMed: 12546357]

Weisbrod AB, Kitano M, Thomas F, et al. Assessment of tumor growth in pancreatic neuroendocrine tumors in von Hippel Lindau syndrome. J Am Coll Surg. 2014; 218:163-169. [PubMed: 24440063]

Werness BA, Guccion JG. Tumor of the broad ligament in von Hippel-Lindau disease of probable mullerian origin. Int J Gynecol Pathol. 1997; 16:282-285. [PubMed: 9421096]

Wilding A, Ingham SL, Lalloo F, et al. Life expectancy in hereditary cancer predisposing diseases: an observational study. J Med Genet. 2012; 49:264-269. [PubMed: 22362873]

Wind JJ, Lonser RR. Management of von Hippel-Lindau disease-associated CNS lesions. Expert Rev Neurother. 2011; 11:1433-1441. [PubMed: 21955200]

Wind JJ, Bakhtian KD, Sweet JA, et al. Long-term outcome after resection of brainstem hemangioblastomas in von Hippel-Lindau disease. J Neurosurg. 2011; 114:1312-1318. [PubMed: 20932100]

Wittström E, Nordling M, Andréasson S. Genotype-phenotype correlations, and retinal function and structure in von Hippel-Lindau disease. Ophthal Genet. 2014; 35:91-106.

Wong WT, Agrón E, Coleman HR, et al. Clinical characterization of retinal capillary hemangioblastomas in a large population of patients with von Hippel-Lindau disease. Ophthalmology. 2008a; 115:181-188. [PubMed: 17543389]

Wong WT, Liang KJ, Hammel K, et al. Intravitreal ranibizumab therapy for retinal capillary hemangioblastoma related to von Hippel-Lindau disease. Ophthalmology. 2008b; 115:19571964. [PubMed: 18789534]

Woodward ER, Eng C, McMahon R, et al. Genetic predisposition to phaeochromocytoma: analysis of candidate genes GDNF, RET and VHL. Hum Mol Genet. 1997; 6:1051-1056. [PubMed: 9215674]

Woodward ER, Buchberger A, Clifford SC, et al. Comparative sequence analysis of the VHL tumor suppressor gene. Genomics. 2000; 65:253-265. [PubMed: 10857749]

Ye DY, Bakhtian KD, Asthagiri AR, et al. Effect of pregnancy on hemangioblastoma development and progression in von Hippel-Lindau disease. J Neurosurg. 2012; 117:818-824. [PubMed: 22937928]

Yuan G, Peng YJ, Reddy VD, et al. Mutual antagonism between hypoxia-inducible factors 1a and $2 a$ regulates oxygen sensing and cardio-respiratory homeostasis. Proc Natl Acad Sci U S A. 2013; 110:E1788-E1796. [PubMed: 23610397]

Zanotelli DB, Bruder E, Wight E, et al. Bilateral papillary cystadenoma of the mesosalpinx: a rare manifestation of Von Hippel-Lindau disease. Arch Gynecol Obstet. 2010; 282:343-346. [PubMed: 20157715]

Zbar B, Kishida T, Chen F, et al. Germline Mutations in the von Hippel-Lindau disease (VrwL) gene families from North America, Europe, and Japan. Hum Mutat. 1996; 8:348-357. [PubMed: 8956040]

Zhuang Z, Frerich JM, Huntoon K, et al. Tumor derived vasculogenesis in von Hippel-Lindau diseaseassociated tumors. Sci Rep. 2014; 4:4102. [PubMed: 24531117]

Zimmer M, Doucette D, Siddiqui N, et al. Inhibition of hypoxia-inducible factor is sufficient for growth suppression of VHL-/- tumors. Mol Cancer Res. 2004; 2:89-95. [PubMed: 14985465] 


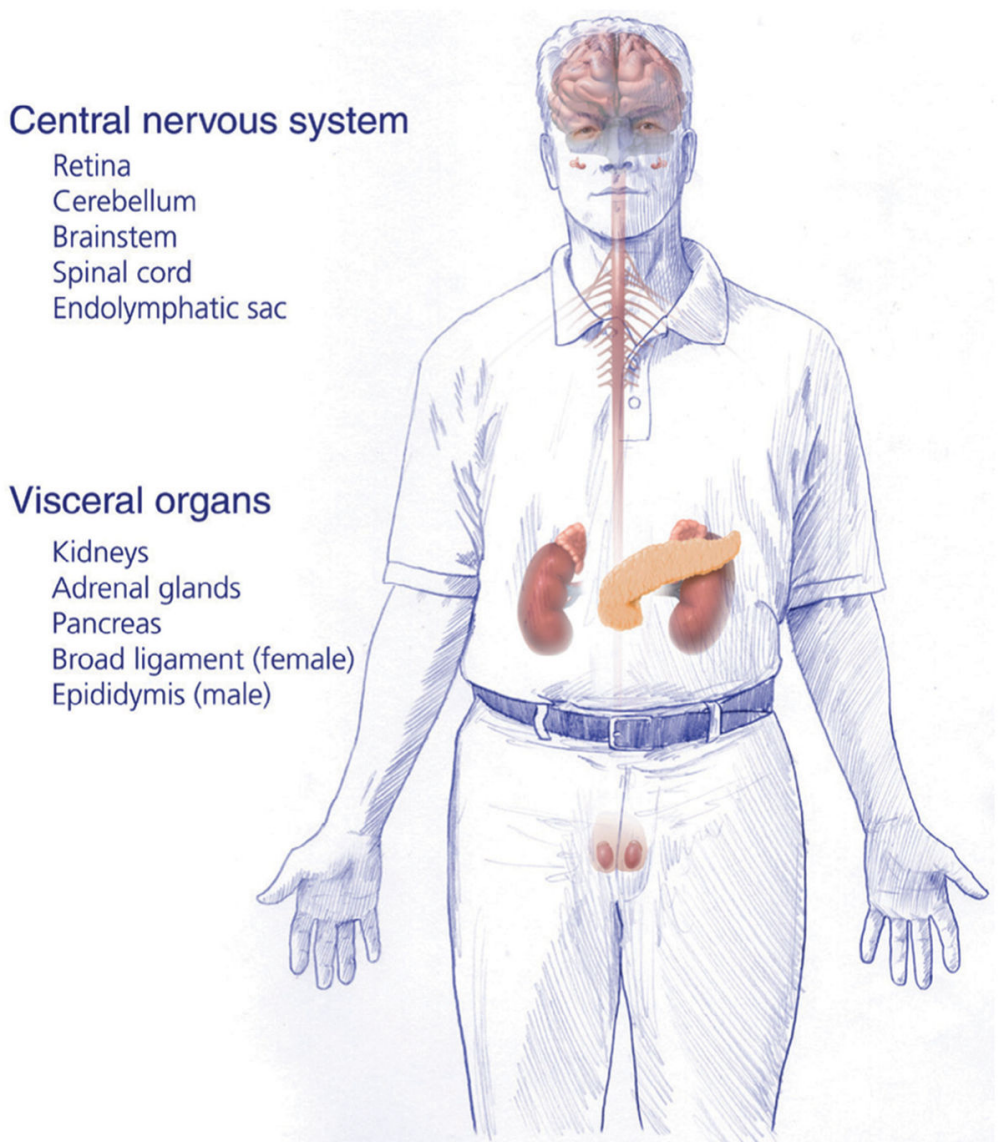

Fig. 10.1.

Organs affected by von Hippel-Lindau disease. 


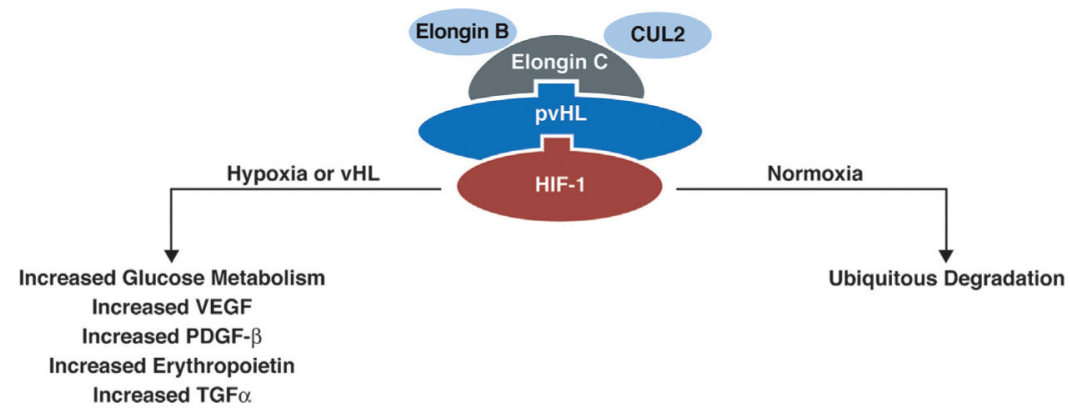

Fig. 10.2.

VCB-CUL2 complex is formed with binding of VHL protein to elongin C, elongin B and CUL2. The complex then binds HIF and leads to degradation in normoxic conditions. (Adapted from Lonser et al., 2003a.) 

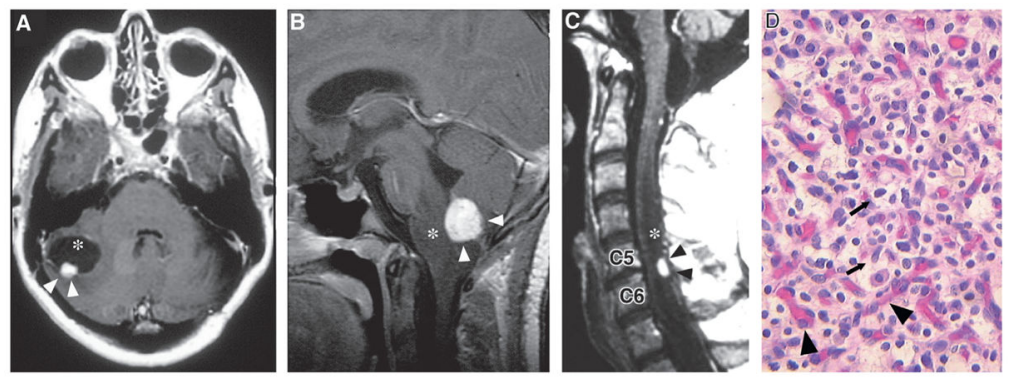

Fig. 10.3.

(A) Axial T1-weighted postcontrast magnetic resonance image (MRI) of a cerebellar hemangioblastoma (arrowheads) with an associated cyst (asterisk) in a 40-year-old woman. (B) Sagittal T1-weighted postcontrast MRI of medullary hemangio-blastoma (arrowheads) with associated brainstem edema (asterisk) in a 12-year-old girl. (C) Sagittal T1-weighted postcontrast MRI of the cervical spinal cord of a 50-year-old man. Hemangioblastoma (black arrowheads) is located in the dorsal spinal cord at C5 and C6, and is associated with a large syrinx (asterix). (D) Hematoxylin and eosin staining of a hemangioblastoma showing the lipid-laden stromal cells (arrows) distributed within a capillary network (arrowheads). (Adapted from Lonser et al., 2003a.) 

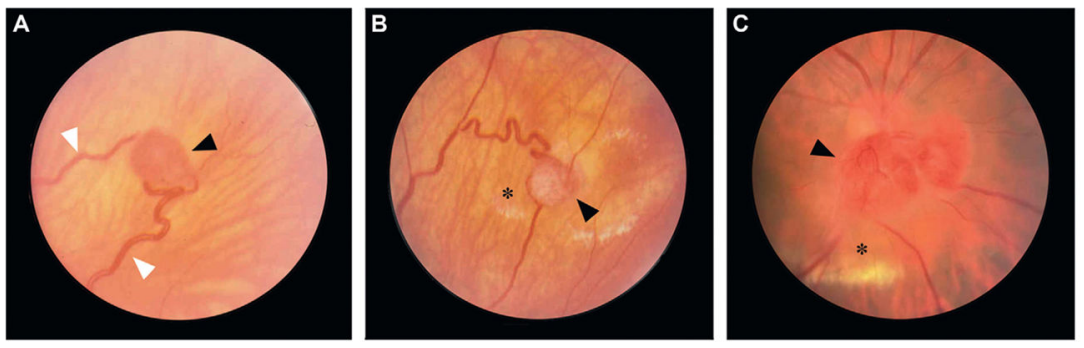

Fig. 10.4.

(A) Peripheral retinal hemangioblastoma (black arrowhead) with enlarged vessels (white arrowheads) in a 22-year-old woman. (B) Peripheral retinal hemangioblastoma (arrowhead) with fibrous changes, and hard exudates and retinal edema (asterisk) in a 24-year-old man.

(C) Retinal hemangioblastoma (arrowhead) on the optic nerve head with yellow retinal hard exudates (asterisk) in a 32-year-old man. (Adapted from Lonser et al., 2003a.) 

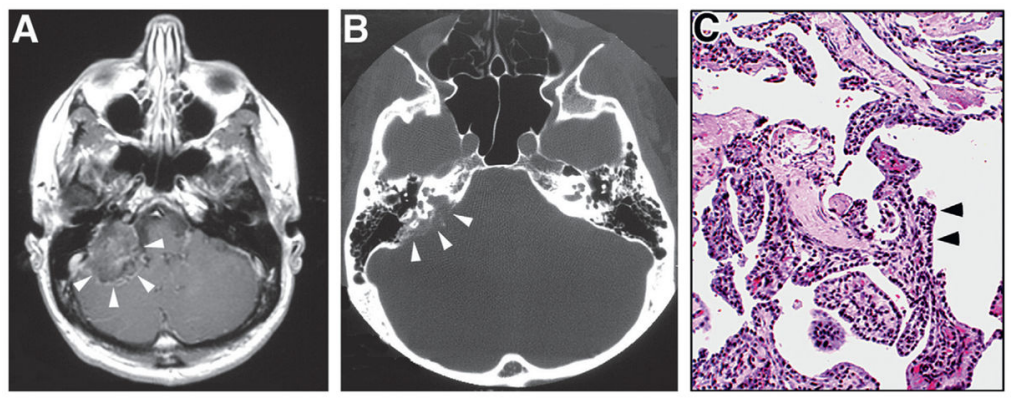

Fig. 10.5.

(A) Axial T1-weighted postcontrast magnetic resonance image shows large heterogeneously enhancing tumor in the right mastoid region (arrowheads). (B) Axial computed tomography through the same region showing the bony erosion of posterior petrous region that often occurs in these tumors (arrowheads). (C) Hematoxylin and eosin stained section showing the typical histologic features of neoplasm, including cuboidal epithelium (arrowheads) in a papillary pattern. (Adapted from Lonser et al., 2003a.) 

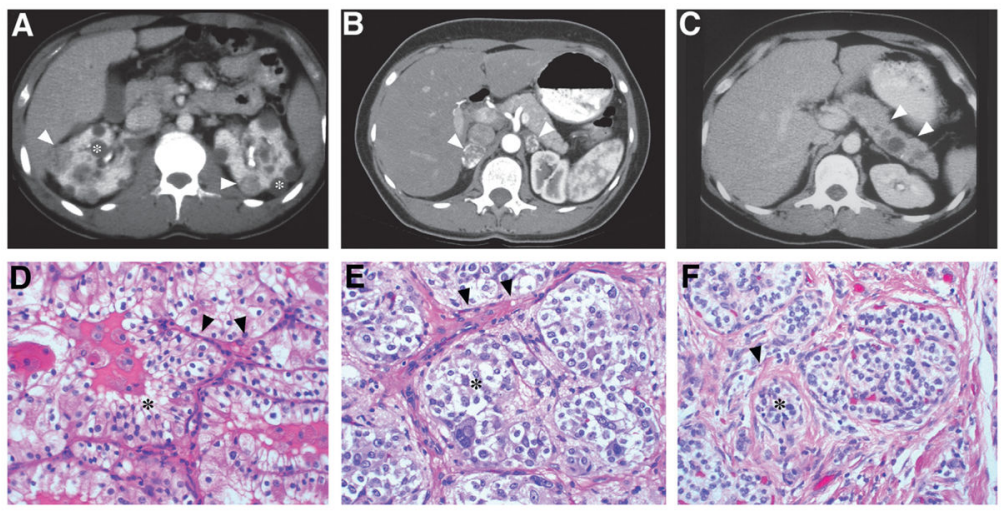

Fig. 10.6.

(A) Bilateral multifocal renal cell carcinoma with both solid (arrowheads) and cystic (asterisk) disease in 22-year-old man. (B) Bilateral pheochromocytomas (arrowheads) with rim enhancement in the adrenal glands of a 29-year-old woman. (C) Pancreatic neuroendocrine tumor (arrowheads) in the body of the pancreas of a 26-year-old woman. (D) Renal cell carcinoma of the clear cell subtype (asterisk) with acinar and tubular architecture embedded in fibrovascular stroma (arrowheads). (E) Pheochromocytomas show a similar appearance and are composed of chromaffin cells. The tumor cells are arranged in rounded clusters (asterisk), separated by endothelial-lined spaces, and have vesicles containing norepinephrine and epinephrine. (F) Pancreatic neuroendocrine tumors show trabecular architecture, small nuclei, and abundant eosinophilic cytoplasm. Nests of tumor cells (asterisk) show focal nuclear atypia with surrounding stromal collagen bands (arrowhead). (Adapted from Lonser et al., 2003a.) 


\section{Table 10.1}

Reported mean age of onset and frequency of lesions

\begin{tabular}{|c|c|c|}
\hline & $\begin{array}{l}\text { Mean (range) of onset } \\
\text { in years }\end{array}$ & $\begin{array}{l}\text { Frequency in } \\
\text { patients }(\%)\end{array}$ \\
\hline \multicolumn{3}{|l|}{ Central nervous system lesions } \\
\hline Retinal hemangioblastoma (Ong et al., 2007; Webster et al., 1998; Wong et al., 2008a) & $25-37(9-84)$ & $15-73 \%$ \\
\hline Endolymphatic sac tumor (Butman et al., 2007; Choo et al., 2004; Manski et al., 1997) & $22-40(11-63)$ & $3-16 \%$ \\
\hline Cerebellar hemangioblastoma (Maher et al., 1990a, b; Ong et al., 2007; Poulsen et al., 2010) & $29-30(13-61)$ & $35-79 \%$ \\
\hline $\begin{array}{l}\text { Brainstem hemangioblastoma (Filling-Katz et al., 1991; Poulsen et al., 2010; Wanebo et al., } \\
\text { 2003) }\end{array}$ & $25-38(16-60)$ & $4-22 \%$ \\
\hline Spinal hemangioblastoma (Maher et al., 1990b; Ong et al., 2007; Poulsen et al., 2010) & $33-34(8-60)$ & $7-53 \%$ \\
\hline $\begin{array}{l}\text { Supratentorial hemangioblastoma (Maddock et al., 1996; Peyre et al., 2010; Poulsen et al., } \\
\text { 2010) }\end{array}$ & $20-29(14-48)$ & $1-7 \%$ \\
\hline \multicolumn{3}{|l|}{ Visceral lesions } \\
\hline Renal cell carcinoma (Maher et al., 1990a, b; Ong et al., 2007) & $40-45(20-69)$ & $30-70 \%$ \\
\hline Renal cyst (Maddock et al., 1996; Poulsen et al., 2010) & $34-39(12-64)$ & $60 \%$ \\
\hline Pheochromocytoma (Binderup et al., 2013; Lonser et al., 2003a; Walther et al., 1999) & $20-29(5-62)$ & $16 \%$ \\
\hline $\begin{array}{l}\text { Pancreatic neuroendocrine tumor (Charlesworth et al., 2012; Hough et al., 1994; Igarashi et } \\
\text { al., 2014) }\end{array}$ & $32-38(16-68)$ & $15-56 \%$ \\
\hline Pancreatic cyst (Charlesworth et al., 2012; Hough et al., 1994; Igarashi et al., 2014) & $29-37(12-63)$ & $21-72 \%$ \\
\hline Epididymal cyst adenoma (Gruber et al., 1980; Lonser et al., 2003a) & $24(10-37)$ & $25 \%$ \\
\hline
\end{tabular}


Table 10.2

Cumulative frequency of first VHL manifestations by age

\begin{tabular}{llll}
\hline Age & Maher et al., 1990b & Poulsen et al., 2010 & Kruizinga et al., 2014 \\
\hline 5 & 0.02 & 0 & \\
15 & 0.19 & 0.31 & \\
25 & 0.52 & 0.62 & \\
35 & 0.78 & 0.70 & \\
45 & 0.91 & 0.95 & \\
55 & 0.96 & 0.98 & \\
65 & 0.99 & & \\
$75+$ & 1.00 & & \\
\hline
\end{tabular}

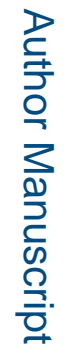

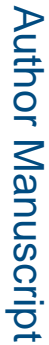

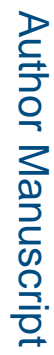

Handb Clin Neurol. Author manuscript; available in PMC 2016 November 24. 


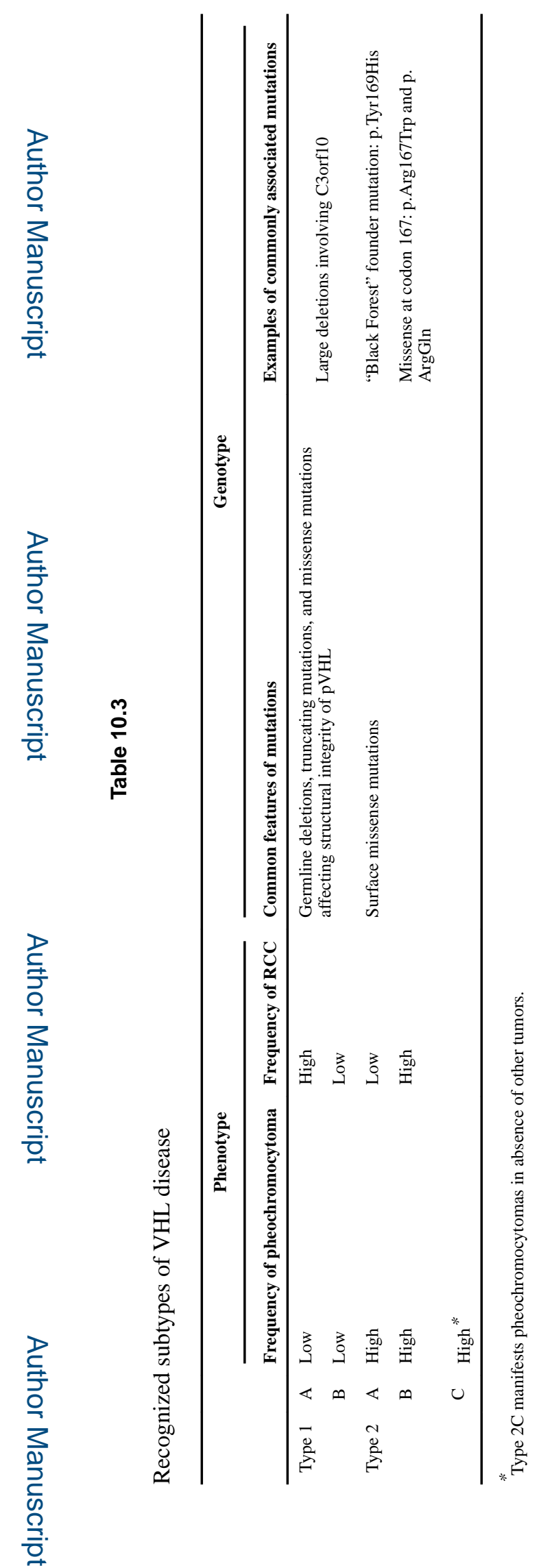

Handb Clin Neurol. Author manuscript; available in PMC 2016 November 24. 


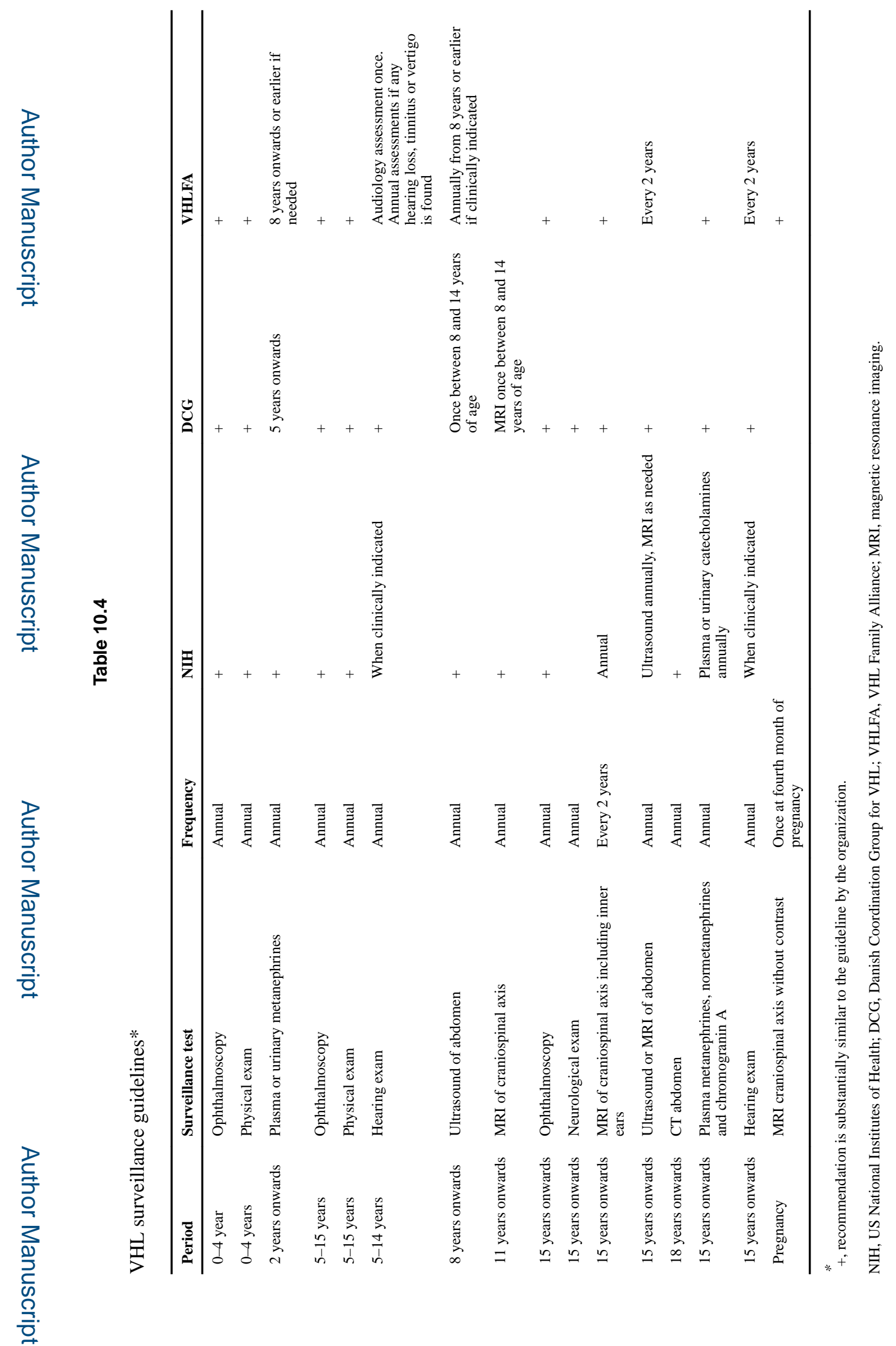

Handb Clin Neurol. Author manuscript; available in PMC 2016 November 24. 